\title{
Cellular Agriculture for Production of Cell-Based Seafood ${ }^{1}$
}

\author{
Razieh Farzad ${ }^{2}$
}

${ }^{*}$ This article intends to give basic information about the cell-based seafood production system to consumers and seafood producers.

\section{Introduction}

Seafood, including fish, crustaceans, and mollusks, supports $17 \%$ of the global demand for animal protein (Costello et al. 2020). Fish demand is projected to increase to 140 metric tons by 2050 due to the anticipated increase in the human population and income (Costello et al. 2020). With the current state of aquaculture and wild-capture fisheries' seafood productions, there is going to be a substantial gap between the supply and demand of seafood in the near future (World Bank 2014). Additionally, the COVID-19 pandemic highlighted the threats to the United States' and global food system security and the importance of sustainable and resilient animal-protein production systems (Éliás et al. 2021; Mardones et al. 2020). This shows an urgent need for a whole new method for seafood production to build a resilient, productive, and flexible enterprise in the face of current and future challenges. While aquaculture and wild-capture fisheries continue to support sustainable seafood production, producing seafood from fish cell and tissue cultures, referred to as cellular agriculture (USDA 2020), is an emerging approach that can help ensure food security in the context of the rising global population, climate change, and competition for natural resources.

\section{Cell-Based Seafood Production Method}

A cell-based seafood production system consists of (1) an appropriate cell type from the tissue of interest; (2) cell culture media to provide nutrients for the growth of the cells; (3) a bioreactor to provide the closed environment to support the development of the cells at a large scale; and (4) a three-dimensional edible tissue scaffold designed to provide structure for cell growth and maturation consistent with the shape of a seafood product that is indistinguishable from its conventional counterpart (Robio et al. 2019). The first step of cell-based seafood production is collecting the cell samples from animal tissue, typically done using biopsy without killing or harming the animal. The harvested cells will then be used to prepare cell banks that can be used later for food production. The next step is taking a small number of cells from the cell bank and placing them in bioreactors, which support growth and cellular multiplication by supplying appropriate nutrients and other factors provided by the cell culture media. After the cells have multiplied many times over into billions or trillions of cells, additional elements such as tissue scaffolds will be added to the bioreactor to provide surfaces for cell attachment, as well as to enable the cells to differentiate into various cell types and assume characteristics of muscle, fat, or connective tissue cells. Then, the cellular material can be harvested from the controlled environment and prepared using conventional food processing and packaging methods (FDA 2020b).

1. This publication is FSHN21-2, one of a series of the Food Science and Human Nutrition Department, UF/IFAS Extension. Original publication date September 2021. Visit the EDIS website at https://edis.ifas.ufl.edu/ for the currently supported version of this publication.

2. Razieh Farzad, assistant professor and seafood safety Extension specialist, Food Science and Human Nutrition Department and Florida Sea Grant, UF/ IFAS Extension, Gainesville, FL 32611.

The Institute of Food and Agricultural Sciences (IFAS) is an Equal Opportunity Institution authorized to provide research, educational information and other services

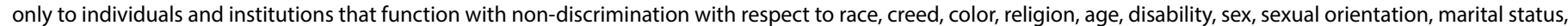

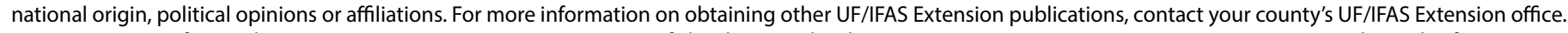
U.S. Department of Agriculture, UF/IFAS Extension Service, University of Florida, IFAS, Florida A \& M University Cooperative Extension Program, and Boards of County Commissioners Cooperating. Nick T. Place, dean for UF/IFAS Extension. 
Other than a muscle-protein production system for goldfish developed in 2002 with NASA funding (Benjaminson et al. 2002), no examples of cell-based seafood products have been published. Most of the research and development is currently happening in the private sector, which is unwilling to share the information with the public.

\section{Challenges and Opportunities for the Cell-Based Seafood Industry}

The current method for cell-based meat production is based on medical tissue engineering using advances in bioengineering and cell biology techniques (Ben-Arye et al. 2019) that have been primarilyconducted within mammalian systems. Fish tissues in vitro have not yet been adequately investigated (Robio et al. 2019). Lack of a proper cell source and a cell culture media that has all the required nutrients and ingredients (i.e., growth factors) for the growth of the cells are the main challenges for cell-based seafood production (Zhang et al. 2020). Muscle contains a mixture of cell types with different proliferative and differentiative capacities. Therefore, identifying which cells to use for culture, proportions of cell types for co-culture, and reprogramming of cells so that they can proliferate and differentiate into the desired cell types are the primary technical challenges (Reiss et al. 2021). Cell culture has been traditionally dependent on Fetal Bovine Serum (FBS), a costly, unsustainable, and inconsistent component in media. The production of cheap, serum-free media remains one of the most pressing limitations for the field (Specht 2020). Also, using additives such as antibiotics in cell culture could cause regulatory and human-health-related concerns. Scale production of cultivated seafood without the need for antibiotics could be challenging and requires a very specialized workforce.

Additionally, the production rates using existing biomanufacturing tools are too slow, expensive, and insufficient for large-scale manufacturing to produce hundreds of millions of meat products (Post et al. 2020; Zhang et al. 2020). The meat harvest process affects the characteristics of muscle from animals, impacting sensory perceptions of the meat products, such as texture and flavor. Therefore, engineering seafood product constructs that mimic sensory perceptions beyond ground products while simultaneously providing better nutrition are critical technical challenges and knowledge gaps (Post et al. 2020). There are no data on the production cost of cell-based seafood, but the current price of cell-based ground beef is $\$ 180-\$ 220$ per kilogram ( $\$ 81-\$ 100$ per pound) compared to its traditional counterpart averaging less than $\$ 9$ per kilogram ( $\$ 4$ per pound).
Culture media comprises 55\%-95\% of the production cost (Specht 2020; Post et al. 2020). The construction of more complex tissue is expected to cost 5-10 times more than cell-cultured ground products per kilogram (Specht 2020).

In addition to the technical challenges, integrating social sciences to understand stakeholder perception is particularly important for a successful food production system that appeals to consumers. One of the main challenges for the industry is deciphering accurate information that can affect consumer and producer acceptance. Shifting cultural and societal ethics toward animal welfare when an equivalent alternative exists will undoubtedly impact all sectors of traditional animal agriculture. Additionally, redesigning education and training from high school through undergraduate, graduate, and current workers is essential for workforce development in a cellular agriculture industry that currently does not exist.

Despite these challenges, cell-based seafood products have the most prominent potential to reach the market at a reasonable price. Modern aquaculture techniques such as genetic modification for seafood production in closed aquaculture systems and studies focused on fish muscle physiology with implications for aquaculture lay the essential groundwork for cell-based seafood production research and development (Robio et al. 2019). Fish cell and tissue culture physiological properties, including hypoxia (low oxygen) tolerance, high buffering capacity (being less sensitive to $\mathrm{pH}$ fluctuations), and low-temperature growth conditions, make marine cell culture an attractive opportunity for scale production of cell-based seafood (Robio et al. 2019). In mammals and birds, the number of muscle cells (fibers) is set at birth; after that, muscle growth is dependent on increases in cell size (length and diameter) (Rossi et al. 2014). On the other hand, muscle growth in fish after hatching is due to the combined effects of an increase in muscle fiber formation and increase in the size of existing fibers. Therefore, it continues throughout the fish life (Kiessling et al. 2006). A similar observation has been found in fish muscle cells grown in culture media, which shows the engineering advantage of the fish cells over mammalian and avian cell-based meat production (Potter et al. 2020). Additionally, seafood is considered an expensive, high-value food commodity, and there are some species of fish, such as tuna, that cannot be produced in a land-based aquaculture facility for their whole life cycle. This makes seafood a great candidate with a high potential for cellular agriculture techniques leading to novel food products on the market at a competitive price. 


\section{Cell-Based Seafood Products Regulations and Labeling}

The Food and Drug Administration (FDA) and the United States Department of Agriculture's Food Safety and Inspection Services (USDA-FSIS) agreed in 2019 to establish a joint regulatory framework for cell-based meat. The FDA would oversee cell collection, cell banks, and cell growth and differentiation, while the USDA would oversee production and labeling of meat developed from cells of livestock and poultry. The FDA, however, has the sole oversight of cell-based seafood (except catfish species) and has called for public comment on how to label it (FDA 2020a). Based on the agreement, FDA regulatory oversight includes a premarket consultation process and inspection of the records and facilities to ensure that the cover entities comply with requirements such as facility registration and the FDA's Current Good Manufacturing Practices, Hazard Analysis Critical Control Point, and Preventive Controls requirements. Imports of foods comprising or containing cell-based fish or seafood cells must meet the same legal requirements as domestically produced foods (FDA 2019).

\section{Conclusion}

The nascent cellular agriculture technology has been proposed as a solution to complement sustainable seafood production through aquaculture and capture fisheries and to supply enough seafood for the growing demand in the future. However, there are still many technical and societal challenges that the cellular agriculture industry needs to overcome before cell-based seafood products enter the US marketplace.

\section{References}

Ben-Arye, T., and S. Levenberg. 2019. “Tissue Engineering for Clean Meat Production." Frontiers in Sustainable Food Systems 3:46. https://doi.org/10.3389/fsufs.2019.00046

Benjaminson, M. A., J. A. Gilchriest, and M.Lorenz. 2002. "In Vitro Edible Muscle Protein Production System (MPPS): Stage 1, Fish.” Acta Astronautica 51 (12): 879-889. https://doi.org/10.1016/S0094-5765(02)00033-4

Choi, K.-H., J. W. Yoon, M. Kim, H. J. Lee, J. Jeong, M. Ryu, C. Jo, and C.-K. Lee. 2021. "Muscle Stem Cell Isolation and In Vitro Culture for Meat Production: A Methodological Review." Comprehensive Reviews in Food Science and Food Safety 20 (1): 429-457. https://doi. org/10.1111/1541-4337.12661
Costello, C., L. Cao, S. Gelcich, M. Á. Cisneros-Mata, C. M. Free, H. E. Froehlich, C. D. Golden, et al. 2020. "The Future of Food from the Sea." Nature 588 (7836): 95-100. https:// doi.org/10.1038/s41586-020-2616-y

Éliás, B. A., and A. Jámbor. 2021. "Food Security and COVID-19: A Systematic Review of the First-Year Experience." Sustainability 13 (9): 5294. https://doi.org/10.3390/ su13095294

FDA. 2019. "Formal Agreement between FDA and USDA Regarding Oversight of Human Food Produced Using Animal Cell Technology Derived from Cell Lines of USDA-amenable Species." Retrieved July 9, 2021. https:// www.fda.gov/food/domestic-interagency-agreements-food/ formal-agreement-between-fda-and-usda-regardingoversight-human-food-produced-using-animal-cell

FDA. 2020a. "FDA Seeks Input on Labeling of Food Made with Cultured Seafood Cells." Retrieved July 9, 2021. https://www.fda.gov/food/cfsan-constituent-updates/ fda-seeks-input-labeling-food-made-cultured-seafood-cells

FDA. 2020b. "Food Made with Cultured

Animal Cells." Retrieved July 9, 2021. https:// www.fda.gov/food/food-ingredients-packaging/ food-made-cultured-animal-cells

Kiessling, A., K. Ruohonen, and M. Bjørnevik. 2006. "Muscle Fiber Growth and Quality in Fish." Archives of Animal Breeding 49 (Special Issue): 137-146. http://hdl. handle.net/11250/297126

Mardones, F. O., K. M. Rich, L. A. Boden, A. I. MorenoSwitt, M. L. Caipo, N. Zimin-Veselkoff, A. M. Alateeqi, and I. Baltenweck. 2020. "The COVID-19 Pandemic and Global Food Security." Frontiers in Veterinary Science 7:578508. https://doi.org/10.3389/fvets.2020.578508

Post, M. J., S. Levenberg, D. L. Kaplan, N. Genovese, J. Fu, C. J. Bryant, N. Negowetti, K. Verzijden, and P. Moutsatsou. 2020. "Scientific, Sustainability and Regulatory Challenges of Cultured Meat." Nature Food 1 (7): 403-415. https://doi. org/10.1038/s43016-020-0112-Z

Potter, G., A. S. T. Smith, N. T. K. Vo, J. Muster, W. Weston, A. Bertero, L. Maves, D. L. Mack, and A. Rostain. 2020. "A More Open Approach Is Needed to Develop Cell-Based Fish Technology: It Starts with Zebrafish." One Earth 3 (1): 54-64. https://doi.org/10.1016/j.oneear.2020.06.005 
Reiss, J., S. Robertson, and M. Suzuki. 2021. "Cell Sources for Cultivated Meat: Applications and Considerations throughout the Production Workflow." International Journal of Molecular Sciences 22 (14): 7513. https://doi.org/10.3390/ ijms 22147513

Rossi, G., and G. Messina. 2014. "Comparative Myogenesis in Teleosts and Mammals." Cellular and Molecular Life Sciences 71 (16): 3081-3099. https://doi.org/10.1007/ s00018-014-1604-5

Rubio, N., I. Datar, D. Stachura, D. Kaplan, and K. Krueger. 2019. "Cell-Based Fish: A Novel Approach to Seafood Production and an Opportunity for Cellular Agriculture." Frontiers in Sustainable Food Systems 3:43. https://doi. org/10.3389/fsufs.2019.00043

Specht, L. 2020. An Analysis of Culture Medium Costs and Production Volumes for Cultivated Meat. The Good Food Institute. https://gfi.org/wp-content/uploads/2021/01/cleanmeat-production-volume-and-medium-cost.pdf

The World Bank. 2014. "Raising More Fish to Meet Rising Demand." Retrieved July 8, 2021. https:// www.worldbank.org/en/news/feature/2014/02/05/ raising-more-fish-to-meet-rising-demand

Zhang, G., X. Zhao, X. Li, G. Du, J. Zhou, and J. Chen. 2020. "Challenges and Possibilities for Bio-manufacturing Cultured Meat." Trends in Food Science \& Technology 97:443-450. https://doi.org/10.1016/j.tifs.2020.01.026 